\title{
HISTOCHEMICAL STUDIES ON THE LEYDIG-CELL- LEUCINE AMINOPEPTIDASE ACTIVITY IN THE GUINEA-PIG TESTIS
}

\author{
SUDHANSU K. DEY, ${ }^{*}$ JAYASREE SEN GUPTA AND C. DEB \\ Department of Physiology, University College of Science and Technology, \\ 92 Acharya Prafulla Chandra Road, Calcutta-9, India
}

(Received 11th August 1972)

\begin{abstract}
Summary. The activity pattern and functional significance of leucine aminopeptidase (LAP) have been studied in the testes of oestrogentreated, cryptorchid and HCG-treated guinea-pigs. The enzyme was present only in the Leydig cells and showed marked fluctuations in its activity pattern, which correlated closely with alterations in the functional activities of the Leydig cells. Hyperfunctioning Leydig cells exhibited enhanced LAP activity, whereas hypofunctioning of these intertubular cells resulted in a diminution in the enzyme activity. The LAP activity in the intertubular Leydig cells may be regarded as a cytochemical marker enzyme in the assessment of Leydig cell function in the guinea-pig testes under varying experimental conditions.
\end{abstract}

\section{INTRODUCTION}

Although diverse reports regarding the functional significance of leucine aminopeptidase (LAP) activity in many tissues (Talanti \& Hopsu, 1961a, b; Hopsu, Riekkinen \& Luostarinen, 1962; Chatterjee, Dey \& Ghosh, 1972) and endocrine glands (Pearse \& Tremblay, 1958; Hopsu \& Talanti, 1960; Talanti \& Hopsu, 1960; Lobel, Rosenbaum \& Deane, 1961) have been communicated, little is known about this enzyme in the vertebrate testis. Nachlas, Monis, Rosenblatt \& Seligman (1960) noticed no LAP activity in the testes of rats. Very recently, Dey \& Deb (1973) successfully demonstrated LAP activity in the testes of different vertebrates. The enzyme has been found to be present in the maturing sperm cells within the seminiferous tubules of toad and pigeon and in the Leydig cells of guinea-pig testis. No LAP activity was evident in the testes of fish, lizard, mouse and rat.

In the present communication, Leydig-cell LAP activity has been observed in oestrogen-treated, cryptorchid and HCG-treated guinea-pigs in order to examine the possibility of a relationship between changes in LAP activity and Leydig-cell function.

\section{MATERIALS AND METHODS}

Twenty male guinea-pigs, weighing about 180 to $200 \mathrm{~g}$, were selected for the

* Present address: Department of Obstetrics and Gynecology, University of Kansas Medical Center, Kansas City, Kansas 66103, U.S.A. 
present experiment. The animals were maintained on a standard diet and allowed free access to water. The animals were allocated to four groups with equal numbers of animals in each group. The animals in Group 1 received oestrogen ( $20 \mu \mathrm{g}$ Ovocyclin in oil/animal/day) subcutaneously daily for 30 days. The second group of animals was made bilaterally cryptorchid and kept in the same conditions for the same period of 30 days. The animals of the third group received intramuscular injections of HCG at a dose level of 75 i.u./animal every alternate day from the 18th day of the experimental period. The animals in the remaining group were given a measured amount of oil and saline and served as controls. The animals in all the groups were killed at the end of the experimental period of 30 days. The testes were immediately dissected out and chopped into pieces with a sharp blade. One portion of the testes was fixed in chilled buffered formol $(10 \%)$ for 3 to $4 \mathrm{hr}$ for demonstration of LAP activity. The other portions of testes along with the prostates of all the animals were fixed in Carnoy's fluid.

For histochemical localization of LAP activity, frozen sections of testes were cut at $15 \mu \mathrm{m}$ and placed on coverslips. Activity was demonstrated in the prepared sections by following the improved method of Nachlas et al. (1960) using L-leucyl-4-methoxy-2-naphthylamide $\mathrm{HCl}$ as substrate. Parallel sections incubated in the substrate-free medium served as controls. Following incubation for $20 \mathrm{~min}$, the sections were mounted in Apathy's medium for microscopical observation. Histochemical tests for LAP activity were also performed on the kidneys of all the animals studied to confirm the specificity of the enzyme activity.

Paraffin-wax-embedded sections of the testes and prostates were prepared by following the usual laboratory procedures and were stained with haematoxylin and eosin for cytological studies.

\section{RESULTS}

Leucine aminopeptidase activity was localized precisely and specifically in the Leydig cells of the normal guinea-pig testis (P1. 1, Fig. 1). In the oestrogentreated guinea-pig, atrophy of the Leydig cells was associated with a marked diminution of LAP activity (Pl. 1, Fig. 2), whereas in the HCG-treated guineapig, a significant increase in LAP activity in the increased numbers of Leydig

\section{EXPLANATION OF PLATE 1}

FIg. 1. Leucine aminopeptidase (LAP) activity in the Leydig cells of a control guinea-pig testis. $\times 96$.

Fig. 2. Diminution in LAP activity in the atrophied testicular Leydig cells of an oestrogentreated guinea-pig. $\times 96$.

Frg. 3. Marked increase in LAP activity in the guinea-pig Leydig cells, which have undergone marked proliferation following HCG administration. $\times 96$.

FIG. 4. The activity of LAP in the Leydig cells in a cryptorchid guinea-pig testis. $\times 96$.

FrG. 5. The prostate gland of a control guinea-pig, showing the appearance of normal functioning. $\times 192$.

FIG. 6. The prostate gland of an oestrogen-treated guinea-pig, showing the appearance of hypofunctioning. $\times 192$.

FIG. 7. The prostate gland of a HCG-treated guinea-pig, showing the appearance of hyperfunctioning. $\times 192$.

FIG. 8. The prostate gland of a cryptorchid guinea-pig, showing absence of castration changes. $\times 192$. 
PI.ATE 1

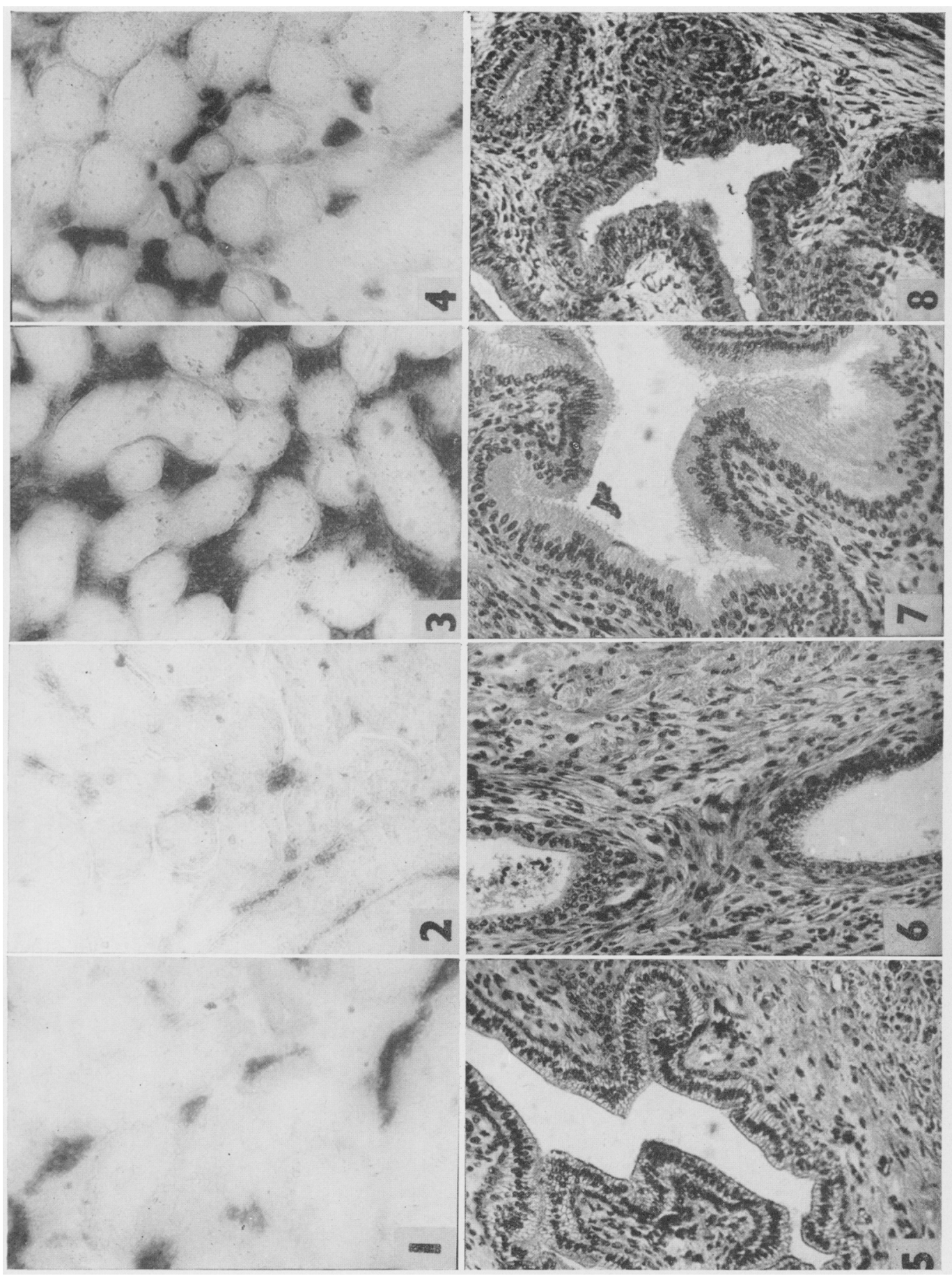

Facing 1.476$)$ 
cells was evident (Pl. 1, Fig. 3). Proliferation of the Leydig cells accompanied by a rise in LAP activity was also noted in the cryptorchid guinea-pig testis (Pl. 1, Fig. 4), but the changes were not so marked as those observed in the case of HCG-treated animals. The intensity of enzyme activity was consistent among the animals of the same group. No LAP activity was present in the control sections incubated in the substrate-free medium. The presence of LAP activity in the kidney tubules confirmed the specificity of the reaction.

In histological sections, the appearance of the prostates of the control animals suggested normal functioning of the gland (Pl. 1, Fig. 5), but, in the oestrogentreated guinea-pig (Pl. 1, Fig. 6), the appearance suggested hypofunction and, following HCG administration (Pl. 1, Fig. 7), a significant increase in the secretory activity of the gland was manifested. No castration changes were observed in the prostates of guinea-pigs with ectopic testes (Pl. 1, Fig. 8).

\section{DISCUSSION}

In the present investigation, proliferation of the Leydig cells associated with a very marked rise in LAP activity was observed in the guinea-pig testis after HCG treatment. Similar results were also obtained in the cryptorchid testis but not to the same degree as in the case of HCG-treated animals. By contrast, atrophy of Leydig cells with diminished LAP activity was noted in oestrogentreated guinea-pig testes compared to those of normal guinea-pigs.

It is known that ICSH or LH promotes Leydig-cell function with proliferation of these cells and evidence of increased androgen synthesis, and HCG appears to act upon the testis in the same way (Samuels \& Helmreich, 1956; Brinck-Johnsen \& Eik-Nes, 1957; Arvy, 1962; Llaurado \& Dominguez, 1963; Ewing \& Eik-Nes, 1966). Heightened activity of the Leydig cell in the guineapig testis following HCG treatment can thus be correlated with an increase in Leydig-cell LAP activity. Hyperplasia of the Leydig cells in the cryptorchid testis has been reported (Lynch \& Schott, 1951; Samisoni, 1966) together with diverse opinions on its androgen production (Moore, 1944; Samuels \& Helmreich, 1956; Kormano, Härkönen \& Kontinen, 1964; Eik-Nes, 1966; Skinner \& Rowson, 1967). No castration changes were observed in the prostate and seminal vesicles of guinea-pigs even after 3 months of cryptorchidism (Antliff \& Young, 1957), though, in other cases, a fall in androgen production has been recorded following induction of cryptorchidism (Morehead \& Morgan, 1967; Inano \& Tamaoki, 1968). A rise in LH concentration in ectopic testis as a result of diminished androgen synthesis has been regarded as the cause of Leydig-cell hyperplasia (Samisoni, 1966), but, in the present investigation, the histological picture of the prostate gland in the cryptorchid guinea-pig indicates a normal or moderate increase in androgen synthesis by the proliferating Leydig cells. The initial fall in androgen synthesis by the cryptochid testis possibly stimulated pituitary gonadotrophin secretion resulting in hyperfunctioning of the Leydig cells as a compensatory mechanism, and the rise in Leydig-cell LAP activity in the cryptorchid testis may be related to this change. Atrophy or degeneration of the Leydig cells and intratubular cells with diminished steroidogenic and metabolic activity following oestrogen treatment is a common phenomenon (Lynch, 
1952; Gosler, Baust \& Tonutti, 1966; Oshima, Wakabayashi \& Tamaoki, 1967), which was observed in the guinea-pig testis after oestrogen administration in the present experiment. The degenerative changes following oestrogen injection have been ascribed to the effects of diminished secretion of pituitary gonadotrophins (Lynch \& Schott, 1951; Gay \& Dever, 1971). A dramatic depression in the size and function of the accessory sex glands after oestrogen administration has also been obtained (Lerner, Hilf \& Harris, 1968). Decreased Leydig-cell LAP activity may be associated with hypofunction and atrophy of these cells and there is supporting evidence from cytological studies of the prostate glands in the oestrogen-treated guinea-pig.

From the present investigations, it can be concluded that LAP activity fluctuates with the changes in Leydig-cell function; hyperfunctioning is associated with increased Leydig-cell LAP activity, and hypofunctioning with diminished enzyme activity. Although the exact rôle of LAP in Leydig-cell function is not well understood, one of the possible functions of Leydig-cell LAP may be associated with protein synthesis. Association of this enzyme with the growth of the ovary following gonadotrophin administration has been reported (Kaneyoshi, 1968). Correlations of LAP activity with polypeptide hormone synthesis in the parathyroids (Pearse \& Tremblay, 1958) and in the gastric mucosa (Talanti \& Hopsu, 1961a) have been noted, but protein synthesis in the mammary gland is known to be independent of LAP activity (Talanti \& Hopsu, 1961b). On the other hand, hydrolytic activity of LAP has been recorded in the accessory sex organs after castration (Hopsu et al., 1962). An increase in protein synthesis in the HCG-treated testis has been reported to stimulate the synthesis of enzyme systems involved in steroidogenesis (Samuels \& Helmreich, 1956). Association of increased Leydig-cell LAP activity with protein synthesis in these cells in the same condition cannot be ruled out. Other possible rôles for this enzyme in the guinea-pig testis may be connected with the differentiation and secretion of the Leydig cells. A correlation between hydrolytic or lysosomal enzyme activity and the secretion of endocrine glands has already been reported (Lobel, Levy \& Lindner, 1970).

Leydig-cell LAP activity in guinea-pig testis can be regarded as providing a reliable index of Leydig-cell function in different experimental conditions as it is precisely localized in these cells and shows fluctuations with Leydig-cell activity. It is hoped that the above observations may represent a first step in an ultimately rewarding line of enquiry.

\section{ACKNOWLEDGMENTS}

The authors are grateful to Organon Laboratories Ltd, Surrey, Great Britain, for their generous supply of HCG. Thanks are also extended to Mrs Anjana Dey of the Indian Statistical Institute, India, for her active help and cooperation in the present investigation. The facilities of the Histochemical Laboratory, Department of Physiology, Calcutta University, are gratefully acknowledged.

\section{REFERENGES}

ANtuif, H. R. \& Young, W. C. (1957) Internal secretory capacity of the abdominal testis in the guinea-pig. Endocrinology, 61, 121. 
Arvy, L. (1962) Action de l'hormone gonadotrope choriale sur quelques activités enzymatiques testiculaires chez le rat. C. r. hebd. Séanc. Acad. Sci., Paris, D225, 1532.

Brinck-Johnsen, T. \& Eik-Nes, K. B. (1957) Effect of human chorionic gonadotropin on the secretion of testosterone and 4-androstene-3,17-dione by the canine testis. Endocrinology, 61, 676.

Chatterjee, A. K., Dey, S. K. \& Ghosh, B. B. (1972) Effect of ascorbic acid administration on serum protein level and kidney aminopeptidase activity in the euthyroid and hypothyroid rat. Endokrinologia experimentalis, 6, 119.

DEy, S. K. \& DEB, C. (1973) Testicular leucine aminopeptidase in different vertebrates. Acta histochem. 45,71 .

EIK-Nes, K. B. (1966) Secretion of testosterone by the eutopic and cryptorchid testis in the same dog. Can. 7. Physiol. Pharmac. 44, 629.

Ewing, L. L. \& EIK-NEs, K. B. (1966) On the formation of testosterone by the perfused rabbit testes. Can. F. Biochem. 44, 1327.

GAY, V. L. \& Dever, N. W. (1971) Effect of testosterone propionate and estradiol benzoate alone or in combination on serum LH and FSH in orchidectomized rats. Endocrinology, 89, 161.

Gosler, H. G., Baust, P. \& TonUtTi, E. (1966) Reaction of some dehydrogenases in the testis of rat, guinea-pig and mouse after estrogen treatment. Acta histochem. 25, 198.

Hopsu, V. K., Riekkinen, P. \& Luostarinen, E. (1962) Hormonal influences of leucine aminopeptidase in the accessory reproductive tracts of the rat. Experientia, 18, 15.

Hopsu, V. K. \& TAlanti, S. (1960) Influence of thyrotropin on the leucine aminopeptidase activity in the thyroid gland of the rat. Annls Med. exp. Biol. Fenn. 38, 427.

INANO, H. \& TAMAOKI, B. (1968) Effect of experimental bilateral cryptorchidism on the testicular enzymes related to androgen formation. Endocrinology, 83, 1074.

Kaneyoshi, A. (1968) Effect of gonadotrophin on the aminopeptidase activities in the rat ovary. Kurashiki Chuo Byoin Nempo, 37, 106. (Chem. Abstr. 71, 120150 м).

Kormano, M., Härkönen, M. \& Kontinen, E. (1964) Effect of experimental cryptorchidism on the histochemically demonstrable dehydrogenases of the rat testis. Endocrinology, 74, 44.

LERNER, L. J., HILF, R. \& HARrIs, D. N. (1968) The effect of antagonists on androgen and estrogeninduced changes in the male accessory sex organs of the rat. Trans. N.Y. Acad. Sci. 30, 783.

Llaurado, J. G. \& Dominguez, O. V. (1963) Effect of cryptorchidism on the testicular enzymes involved in androgen biosynthesis. Endocrinology, 72, 292.

LOBes, B. L., Levy, E. \& Lindner, H. R. (1970) Cytochemical studies on oviducts of the rat during the estrous cycle and progestation. In: Mechanisms Involved in Conception, Schering Symposium, Berlin, p. 315. Ed. G. Raspé. Pergamon Press, Vieweg.

Lobel, B. L., Rosenbaum, R. M. \& Deane, H. W. (1961) Enzymic correlates of physiological regression of follicles and corpora lutea in ovaries of normal rats. Endocrinology, 68, 232.

LyNch, K. M., JR (1952) Recovery of rat testis following estrogen therapy. Ann. N.Y. Acad. Sci. 55, 734.

LYNCH, K. M., JR \& SchotT, W. W. (1951) Lipid distribution in the Sertoli cell and Leydig cell of the rat testis as related to experimental alterations of the pituitary-gonad system. Endocrinology, 49, 8.

Moore, G. R. (1944) Hormone secretion by experimental cryptorchid testes. Yale 7. Biol. Med. 17, 203.

Morehead, J. R. \& Morgan, C. F. (1967) Cryptorchidism: its pre- and post-pubertal effects on the hypophysis of the rat. Fert. Steril. 18, 530.

Nachlas, M. M., Monis, B., Rosenblatt, D. \& Seligman, A. M. (1960) Improvement in the histochemical localization of leucine aminopeptidase with a new substrate, L-leucyl-4-methoxy-2naphthylamide. F. biophys. biochem. Cytol. 7, 261.

Oshima, H., Wakabayashi, K. \& Tamaoki, B. (1967) The effect of synthetic estrogen upon the biosynthesis in vitro of androgen and luteinizing hormone in the rat. Biochem. biophys. Acta, 137, 356.

Pearse, A. G. E. \& TREMBLAY, G. (1958) Leucine aminopeptidase in rat parathyroid and its relation to parathyroid hormone production. Nature, Lond. 181, 1532.

Samisoni, J. I. (1966) The effects of cryptorchidism on the growth and metabolic activity of the testis. M.Sc. thesis, University of Queensland, Brisbane, Australia.

Samuels, L. T. \& Helmreich, M. L. (1956) The influence of chorionic gonadotropin on the $3 \beta$-oldehydrogenase activity of testes and adrenals. Endocrinology, 58, 435.

SkinNer, J. D. \& Rowson, L. E. A. (1967) Effect of unilateral cryptorchidism on sexual development in the pubescent animal. F. Reprod. Fert. 14, 349.

Talantr, S. \& Hopsu, V. K. (1960) The influence of methyl thiouracil on the leucine aminopeptidase activity in the thyroid gland of the rat. Acta endocr., Copenh. 35, 481.

TAlAnTI, S. \& Hopsu, V. K. (196I a) Leucine aminopeptidase in the gastric mucosa of the adrenalectomized rat. Endocrinology, 68, 184 (Abstr.).

TAlanti, S. \& Hopsu, V. K. (1961b) Leucine aminopeptidase in the mammary gland of the cow and rat. Nature, Lond. 191, 86. 